Wi ol e † ta Junik ORCID: 0000-0002-4535-5302

Uniwersytet Kazimierza Wielkiego w Bydgoszczy

\section{Koncepcja rozwoju systemu profilaktyki i kształcenia specjalistów w zakresie profilaktyki zachowań ryzykownych dzieci i młodzieży w Ukrainie}

\author{
A Concept of the Development of a Prevention \\ System and the Education of Specialists in the \\ Prevention of Risky Behaviors in Children and the \\ Youth in Western Ukraine
}

\begin{abstract}
ABSTRAKT
Celem artykułu jest zaprezentowanie projektu badań stosowanych, będqcego przykładem dobrej praktyki w zakresie międzynarodowej współpracy akademickiej na rzecz budowania systemu profilaktyki opartej na dowodach naukowych w zachodniej Ukrainie. Polska jako kraj sqsiadujący jest otwarta na dzielenie się doświadczeniami i osiqgnięciami w wypracowywaniu skutecznych, systemowych rozwiqzań dotyczq̨cych problemów alkoholowych i narkotykowych, którymi zainteresowana jest Ukraina. Potwierdzeniem tego jest prezentowany projekt, realizowany we współpracy z kadrq akademickq z Państwowego Uniwersytetu Pedagogicznego im. Iwana Franki w Drohobyczu. Jego celem jest opracowanie koncepcji i modułu kształcenia dla kierunków studiów przygotowujacych studentów do
\end{abstract}

SLOWA KLUCZOWE

polsko-ukraińska współpraca, projekt badań stosowanych, kształcenie akademickie, moduł kształcenia, profilaktyka zachowan ryzykownych, nauka o profilaktyce, profilaktyka oparta na dowodach naukowych, kadra akademicka, studenci

\section{KEYWORDS}

Polish-Ukrainian cooperation, applied research project, academic education, education module, risky behavior prevention, prevention science, evidence-based prevention, academic staff, students

SPI Vol. 22, 2019/3

ISSN 2450-5358

e-ISSN 2450-5366

DOI: 10.12775/SPI.2019.3.001

Nadesłano: 25.08.2019 Zaakceptowano: 16.10.2019

Artykuły i rozprawy 
pracy profilaktycznej z dziećmi i młodzieżq. Realizatorem projektu jest zespół z Uniwersytetu Kazimierza Wielkiego w Bydgoszczy, kłóry ma ponad dwudziestoletnie doświadczenie w przygotowywaniu pedagogów społecznych do realizacji zadań profilaktycznych. Artykuł zawiera empiryczne uzasadnienie potrzeby realizacji projektu oraz opisy jego celów szczegółowych, przedmiotu, metody działania i charakterystykę kolejnych etapów. Omówiono w nim trudności napotkane na etapie projektowania i realizacji oraz efekt końcowy.

\section{ABSTRACT}

The goal of the article is to present an applied research project which sets an example of best practice in international academic cooperation for building an evidence-based prevention system in Western Ukraine. As a neighboring country, Poland is open to sharing its experience and achievements in attaining effective systematic solutions regarding alcohol and drug issues, which is of interest to Ukraine and is confirmed by the execution of the presented project, realized in cooperation with the academic staff of the Drohobych Ivan Franko State Pedagogical University. The aim of the project is to develop a conceptual and educational module for courses preparing students for prevention work with children and the youth. The project was implemented by a team from the Kazimierz Wielki University in Bydgoszcz, which has over twenty years of experience in preparing social educators for the implementation of preventive tasks. The article contains the empirical foundation, the need for the fulfillment of the project, the descriptions of its goals, subject, method of action and implementation stages. It discusses the difficulties encountered at the design and implementation stages, and the final results.

\section{Wstęp}

W artykule przedstawiono projekt badań stosowanych pod nazwą „Polsko-ukraińska współpraca naukowo-metodyczna na rzecz wspierania rozwoju systemu profilaktyki i kształcenia specjalistów w zakresie przeciwdziałania zachowaniom ryzykownym dzieci i młodzieży na Ukrainie"1. Celem projektu było opracowanie koncepcji i modułu

1 Projekt jest finansowany ze środków przyznanych w trybie konkursowym autorce projektu Wioletcie Junik przez Państwową Agencję Rozwiązywania 
kształcenia ${ }^{2}$ przygotowującego studentów kierunków studiów: praca socjalna i psychologia praktyczna do pracy w dziedzinie profilaktyki zachowań ryzykownych dzieci i młodzieży w Państwowym Uniwersytecie Pedagogicznym im. Iwana Franki w Drohobyczu (PUPIF). Autorka projektu założyła, że moduł ten zostanie opracowany przez zespół złożony z kadry akademickiej PUPIF $^{3}$ i praktyków realizujących na co dzień działania profilaktyczne w środowisku lokalnym Drohobycza ${ }^{4}$ w wyniku współpracy z zespołem z Katedry Pedagogiki Opiekuńczej i Profilaktyki Społecznej Uniwersytetu Kazimierza Wielkiego w Bydgoszczy (KPOiPS UKW ${ }^{5}$ ) i specjalistów zaproszonych spoza UKW ${ }^{6}$. Jego teoretyczną podstawą będzie natomiast nauka o profilaktyce (prevention science).

Problemów Alkoholowych (PARPA) na realizację zadania nr 56/3.5/17/ DEA pn. „Współpraca zagraniczna mająca na celu rozwijanie systemu profilaktyki i kształcenia specjalistów w dziedzinie profilaktyki zachowań ryzykownych dzieci i młodzieży na Ukrainie". (Umowa nr 36/56/3.5/17/DEA pomiędzy PARPA i UKW z dnia 21 września 2017 rok). Wysokość alokacji: $443.273 \mathrm{zt}$.

2 W projekcie moduł kształcenia rozumiany jest jako blok z określoną liczbą przedmiotów nauczania, ułożonych w logiczną całość. Projekt nie polega na opracowywaniu koncepcji modułu charakterystycznego dla nowoczesnego rozumienia kształcenia modułowego, w którym treści kształcenia w zawodzie podzielone są na moduły (nie występuje tu ujęcie przedmiotowe), stanowiące odrębne jednostki kształcenia, łączące w sobie naukę praktycznych umiejętności oraz pozyskiwanie niezbędnej wiedzy teoretycznej. Zespół KPOiPS ma na swoim koncie wdrożenie kształcenia modułowego, jednak nie można było złożyć takiej propozycji do oferty konkursowej z uwagi na przeszkody formalne związane z obowiązującym systemem kształcenia w Ukrainie.

3 Skład osobowy zespołu kadry akademickiej PUPIF: S. Shchudlo - koordynator projektu, L.Vovk, V. Stets, I. Mirchuk, L. Smerechak, I. Zubrytsky, R. Havula.

4 Skład osobowy zespołu praktyków-profilaktyków: o. I. Kozankiewicz - lider zespołu, A. Kozankiewicz, A. Slavych, M. Horychko, N. Pankov, I. Tomishchak, T. Poturaj.

5 Skład osobowy zespołu KPOiPS: W. Junik - kierownik projektu, M. Deptuła, J. Jarczyńska, A. Potorska, S. Borsich.

6 Skład osobowy zespołu ekspertów zewnętrznych: A. Borucka - Krajowe Biuro do spraw Przeciwdziałania Narkomanii w Warszawie, A. Pisarska - Instytut Psychiatrii i Neurologii w Warszawie, M.J. Sochocki - Fundacja Poza Schematami z Warszawy. 
Projekt jest pierwszym tego typu przedsięwzięciem realizowanym w zachodniej Ukrainie za pośrednictwem polskiej instytucji rządowej. Rozpoczął się w czerwcu 2017, a zakończy się w grudniu 2019 roku.

\section{Uzasadnienie potrzeby realizacji projektu}

Przygotowanie projektu poprzedziło określenie potrzeb w zakresie rozwoju systemu profilaktyki na rzecz dzieci i młodzieży na Ukrainie. Obejmowało ono poznanie przez autorkę projektu szerszego kontekstu społecznego problemów dzieci i młodzieży oraz stosowanych rozwiązań profilaktycznych w tym kraju. Problemy młodego pokolenia ukraińskiego, podobnie jak w innych krajach, są pochodną sytuacji społecznej, gospodarczej, ekonomicznej i politycznej. Mają też bezpośredni związek z kondycją społeczeństwa ukraińskiego, która w zakresie zdrowia publicznego w świetle statystyk organizacji międzynarodowych jest niekorzystna. Świadczyły o tym między innymi wskaźniki demograficzne z 2017 roku zawarte w The World Factbook dotyczące długości życia, śmiertelności obywateli, w tym niemowląt i matek (The World Factbook 2016-17, 2016). Źródłem nasilania się problemów społecznych Ukrainy jest zmiana ustroju politycznego, transformacja gospodarcza i sytuacja geopolityczna, w tym osamotnienie $\mathrm{w}$ zmaganiu się $\mathrm{z}$ rosyjską agresją militarną rozpoczętą w lutym 2014 roku związaną z aneksją Krymu i wojną w Donbasie ${ }^{7}$. Według Światowej Organizacji Zdrowia (WHO) w wyniku działań zbrojnych wzrasta liczba ofiar śmiertelnych i doznających uszczerbku na zdrowiu, powstają zagrożenia epidemiologiczne i mają miejsce migracje społeczne do innych części kraju lub za granicę (por. World Health Organization: Ukraine. Conflict emergency). Kolejny poważny problem wskazany przez WHO to niepokojące, na tle państw Unii Europejskiej wskaźniki konsumpcji alkoholu (por. World Health Organization: Ukraine. Statistics).

Te i inne dane dotyczące kondycji społeczeństwa ukraińskiego uzasadniają nazwanie go społeczeństwem ryzyka, w którym $\mathrm{w}$ wielu obszarach konieczna jest systemowa interwencja

7 Sytuacja we wschodniej Ukrainie jest ciągle napięta. Przemoc trwa pomimo porozumień o zawieszeniu broni podpisanych 19.07.2017 roku (por. World Health Organization: Ukraine health situation reports). 
(por. Szczudło 2014: 174). Analiza wyników badań ESPAD ${ }^{8}$, zrealizowanych w 2015 roku na terenie całej Ukrainy oraz przeprowadzonych lokalnie w obwodzie lwowskim w 2016 roku na podstawie metodologii tzw. Badań mokotowskich, ukazała szereg zagrożeń dla prawidłowego rozwoju psychospołecznego tamtejszej młodzieży. Wśród nich największe rozmiary przybierały zjawiska związane z używaniem legalnych i nielegalnych substancji psychoaktywnych (zob. Balakireva i in. 2015; Okulicz-Kozaryn i in. 2017).

Argumentem na rzecz współpracy było też poznanie przez autorkę projektu dotychczas stosowanych rozwiązań profilaktycznych na rzecz młodego pokolenia, zwłaszcza takich, które miałyby charakter działań długofalowych, systemowych. Wstępna analiza ustawodawstwa obowiązującego w Ukrainie ujawniła wysiłki podejmowane w tym kierunku przez władze państwowe. W 2013 roku Rada Ministrów Ukrainy wydała pierwszy dekret w sprawie zatwierdzenia państwowej strategii antynarkotykowej na okres do 2020 roku, która opierałaby się na rozwiązaniach charakterystycznych dla zachodnich modeli rozwiązywania problemów narkomanii (Кабінет Міністрів України 2013).

Kolejnym argumentem był fakt, że w Ukrainie na poziomie szkolnictwa wyższego nie było formalnych rozwiązań dotyczących kształcenia przyszłych specjalistów w zakresie profilaktyki zachowań ryzykownych dzieci i młodzieży. $Z$ tego powodu propozycja zainicjowania takiego kształcenia na terenie PUPIF spotkała się z zainteresowaniem i aprobatą władz oraz kadry akademickiej kształcącej psychologów i pracowników socjalnych, które zapewniły, że istnieje organizacyjna możliwość wdrożenia wypracowanych w projekcie rozwiązań.

\section{Inicjowanie współpracy}

Ogłoszenie konkursowe było odpowiedzią na zapotrzebowanie konkretnego środowiska lokalnego. W 2016 roku PARPA, PUPIF

8 Mowa o Europejskim Projekcie Badań Szkolnych na temat Alkoholu i innych Narkotyków (ang. European School Survey Project on Alcohol and Drugs), zainicjowanych w 1995 roku przez Cooperation Group to Combat Drug Abuse and Illicit Trafficking in Drugs (Pompidou Group) działającej przy Radzie Europy. 
i Fundacja Charytatywna „Caritas Diecezji Samborsko-Drohobyckiej UGCC" nawiązały współpracę partnerską na rzecz rozwoju profilaktyki uzależnień wśród młodzieży ${ }^{10}$. Pierwszym zadaniem autorki projektu było nawiązanie wspólpracy z tymi instytucjami, celem poznania ich potrzeb i porozumienia się co do zasadniczych kwestii związanych z jego realizacją.

Projekt miał się przyczynić do zainicjowania przez polski zespół pewnej zmiany społecznej w różniącej się kulturowo społeczności ukraińskiej, bliżej nieznanej realizatorom projektu. Jego autorka zaproponowała więc stronie ukraińskiej współpracę opartą na zasadach partnerskich. Za istotne uznała przestrzeganie zasad podmiotowości i egalitaryzmu, sytuujących każdą ze stron na pozycji partnera. Głównym sposobem urzeczywistniania takiego podejścia było przyjęcie idei „kultury współpracy”, która dla partnerów projektu przejawia się $\mathrm{w}$ akcentowaniu norm, wartości, przekonań i założeń dotyczących współdziałania z innymi, wzajemnego wspierania się, wspólnego poszukiwania rozwiązań doświadczanych problemów, wspólnego celebrowania odnoszonych sukcesów, uczenia się od siebie nawzajem (zob. Maslowski 2006 za: Tłuściak-Deliowska i Dernowska 2016: 130). Przyjęto, że istotą projektu jest „dzielenie się zasobami”, a nie „udzielanie wsparcia” rozumianego często jako podtrzymywanie, ochranianie czy opieka. Spodziewanym rezultatem dbałości o kulturę współpracy miało być uczenie się od siebie i powstanie modułu kształcenia odpowiadającego standardom naukowej profilaktyki, którego autorami i realizatorami będą partnerzy ukraińscy.

$\mathrm{Z}$ uwagi na krótki termin składania wniosku na konkurs organizowany przez PARPA i brak środków finansowych niemożliwe było zaplanowanie osobistych spotkań z partnerami ukraińskimi na etapie przygotowywania projektu. Dlatego też złożenie deklaracji

9 Fundacja ta jest publiczną organizacją charytatywną typu non-profit. Działa od 2000 roku. Jej misją jest pomoc najbardziej potrzebującym, bez względu na religię, płeć, poglądy polityczne lub narodowość, a celem niesienie pomocy osobom w kryzysie, przeciwdziałanie biedzie i patologiom społecznym, walka z kryzysem społecznym na Ukrainie. Fundacja współpracuje z wieloma instytucjami w Europie i poza nią, ale szczególnie intensywnie z partnerami z Polski.

10 W dniu 19 października 2016 roku K. Brzózka (dyrektor PARPA), N. Skotna (rektor PUPIF) i o. I. Kozankiewicz (dyrektor Fundacji „Caritas”) podpisali umowę w tej sprawie. 
o uczestnictwie w projekcie konkretnych zespołów kadry akademickiej z PUPIF i wybranych przedstawicieli środowiska lokalnego oraz wybór koordynatorki po stronie ukraińskiej ${ }^{11}$ przeprowadzono za pośrednictwem korespondencji elektronicznej i kontaktów telefonicznych.

\section{Cel projektu}

Ostatecznie cel projektu sformułowano jako opracowanie koncepcji i modułu kształcenia przygotowującego studentów na kierunkach psychologia praktyczna i praca socjalna PUPIF do pracy w dziedzinie profilaktyki zachowań ryzykownych dzieci i młodzieży. Do realizacji takiego modułu niezbędne są zasoby w postaci osób posiadających wiedzę i umiejętności z zakresu projektowania procesu kształcenia w szkolnictwie wyższym, znających teoretyczne i empiryczne podstawy profilaktyki zachowań ryzykownych dzieci i młodzieży oraz mogących towarzyszyć studentom w zdobywaniu przez nich doświadczeń praktycznych.

\section{Charakterystyka partnerów ukraińskich}

Projekt zaadresowano zatem do dwóch grup nazywanych bezpośrednimi i pośrednimi grupami docelowymi. Bezpośrednia grupa docelowa liczyła 14 osób, a utworzyło ją 7 nauczycieli akademickich z PUPIF pracujących na wyżej wymienionych kierunkach studiów i zainteresowanych wprowadzaniem zmiany w procesie kształcenia. W jej skład weszło także 7 przedstawicieli środowiska lokalnego realizujących na co dzień zadania z zakresu profilaktyki społecznej. Byli to psychologowie, terapeuci uzależnień, nauczyciele szkół podstawowych i osoba duchowna specjalizująca się w pomocy społecznej i profilaktyce uzależnień. Zadaniem tej grupy było opracowanie wspólnie z nauczycielami akademickimi koncepcji kształcenia praktycznego uzupełniającego teoretyczną część modułu. Pośrednią grupą docelową zostali studenci kierunków psychologia praktyczna i praca

11 Koordynatorem projektu ze strony ukraińskiej została prof. dr Svitlana Shchudlo - kierownik Katedry Prawoznawstwa, Socjologii i Politologii PUPIF i Centrum Monitorowania Jakości Kształcenia PUPIF. 
socjalna oraz inne podmioty zainteresowane profilaktyką zachowań ryzykownych dzieci i młodzieży w społeczeństwie ukraińskim (za sprawą publikacji naukowych przygotowanych $\mathrm{w}$ ramach projektu).

\section{Przedmioł oddziaływań projekłowych}

Z powodu niemożności nawiązania bezpośredniej współpracy przez kierownika projektu z partnerami ukraińskimi na etapie składania wniosku, zadania w projekcie zostały zaprojektowane na takim poziomie ogólności, żeby z jednej strony spełnić wymagania konkursowe, z drugiej zaś móc wypełnić je treścią w toku późniejszej współpracy ze stroną ukraińską. Zaplanowano więc rozpoznanie zasobów i potrzeb $\mathrm{w}$ trakcie seminariów i badań online oraz dyskusji między partnerami. Punktem odniesienia była wiedza naukowa o profilaktyce dotycząca projektowania, realizowania i ewaluowania zadań profilaktycznych adresowanych do ogółu populacji dzieci i młodzieży (czyli w obszarze profilaktyki uniwersalnej), którą od wielu lat gromadzili partnerzy ze strony polskiej podczas wymiany bezpośredniej z partnerami z krajów Europy Zachodniej, studiowania literatury zachodniej i własnych badań empirycznych. Ważne było także ponad dwudziestoletnie doświadczenie zespołu z KPOiPS w zakresie przygotowywania pedagogów do podejmowania zadań profilaktycznych oraz własne doskonalenie zawodowe polskich partnerów i doświadczenie między innymi w pracy z dziećmi, młodzieżą i nauczycielami.

To, jaki zakres wiedzy i umiejętności jest niezbędny do realizacji zadań z zakresu profilaktyki zachowań ryzykownych w praktyce, wynika z teoretycznej interpretacji zachowań ryzykownych, którym ma przeciwdziałać profilaktyk. Dziś definiuje się je jako te, które łączą się z wystąpieniem zagrożeń na wielu płaszczyznach funkcjonowania młodego człowieka. Wskazuje się na ryzyka związane z prawidłowym rozwojem, bezpieczeństwem, zdrowiem i karierą szkolną czy zawodową, które w konsekwencji mogą prowadzić do pogorszenia jakości życia (Ostaszewski 2017). Stąd w świetle dostępnej dziś wiedzy profilaktyka zachowań ryzykownych oznacza konieczność skoncentrowania się na stylu życia młodych ludzi, ponieważ wiele różnych zachowań ryzykownych ma wspólne przyczyny i funkcje czy też współwystępuje w okresie adolescencji (Ostaszewski 2014). 
W rezultacie główny cel projektu został uszczegółowiony, a działania podzielone na etapy.

\section{Metoda realizacji działań}

Jako metodę realizacji celów szczegółowych wybrano transfer wiedzy. Przyjęto szerokie rozumienie wiedzy, traktując ją jako „zasób, na który składa się wszystko (fakty, zjawiska i związki między nimi), co zostało świadomie spostrzeżone i zarejestrowane (w dowolny sposób zapamiętane, jako byty realne lub konceptualne) oraz możliwe do przekazania innym, stosownie do intencji posiadającego wiedzę w konkretnych warunkach i sytuacji dla wzbudzenia określonych zachowań” (Franke 2016). Transferowaną obustronnie wiedzę można zaliczyć zgodnie z klasyfikacją OECD (2000) do następujących kategorii:

- wiedzieć co (know-what) - odnosi się do typowej wiedzy o faktach (np. wyniki badań naukowych z obszaru profilaktyki naukowej);

- wiedzieć dlaczego (know-why) - dotyczy praw, które zachodzą w naturze, w ludzkim umyśle czy w społeczeństwie (np. wiedza o uwarunkowaniach podejmowania zachowań ryzykownych przez człowieka);

- wiedzieć jak (know-how) - dotyczy umiejętności wykonywania konkretnych zadań czy czynności (np. wiedza o rozwiązaniach metodycznych stosowanych w oddziaływaniach profilaktycznych);

- wiedzieć kto (know-who) - wskazuje kto jest specjalistą w określonej dziedzinie wiedzy, jaki jest jego zakres wiedzy i jakie ma zdolności, aby móc przekazywać ją podmiotom potrzebującym wiedzy (np. wiedza o autorach programów profilaktycznych).

Transfer wiedzy przyjął formę doskonalenia zawodowego, w trakcie którego partnerzy ukraińscy mogli rozwijać swoje kompetencje zawodowe do realizacji zadań profilaktycznych oraz kompetencje do projektowania procesu kształcenia kadr profilaktycznych uczestnicząc w wykładach, warsztatach, ćwiczeniach czy wizytach studyjnych. Proponowane na poszczególnych seminariach formy i treści doskonalenia zawodowego zostały ułożone w bloki tematyczne odnoszące 
się do aktualnego stanu wiedzy z zakresu profilaktyki opartej na naukowych podstawach. Strona polska zdobywała wiedzę o realiach życia społecznego i funkcjonowania instytucji związanych z profilaktyką społeczną oraz specyfice procesu kształcenia w szkolnictwie różnych szczebli.

\section{Etapy realizacii projektu}

Realizację projektu zaplanowano w dwóch etapach. Pierwszy etap poświęcony był przygotowaniu merytorycznemu kadry akademickiej i profilaktyków-praktyków do opracowania koncepcji i modułu kształcenia z zakresu profilaktyki zachowań ryzykownych dzieci i młodzieży opartych na naukowych podstawach zgodnie ze standardami kształcenia na poziomie wyższym określonymi w zasadach Systemu Bolońskiego i przyjętymi na PUPIF. Drugi etap obejmował działania bezpośrednio związane $\mathrm{z}$ opracowywaniem przez partnerów ukraińskich modułu kształcenia we współpracy z nauczycielami akademickimi z KPOiPS UKW.

\section{Etap I}

Zasadnicze działania zaplanowane na tym etapie i sposoby ich realizacji wynikały z założenia, że opracowanie koncepcji i modułu kształcenia nowoczesnych profilaktyków wymaga znajomości aktualnego stanu wiedzy z zakresu profilaktyki opartej na naukowych podstawach oraz posiadania określonych umiejętności niezbędnych do projektowania procesu kształcenia w oparciu o naukowe przesłanki i obowiązujące przepisy prawa. Dlatego tak ważne było znalezienie wspólnego języka opisu kompetencji, dzięki któremu partnerzy ukraińscy mogli rozpoznać własne potrzeby i zasoby oraz poznać potrzeby i zasoby studentów, dla których moduł kształcenia miał powstać. W tym celu zaplanowano szereg konsultacji online oraz diagnozę online.

Badanie online przeprowadzono za pośrednictwem kwestionariusza ankiety ${ }^{12}$ zamieszczonego na platformie „Ankieta +”. Narzędzie

12 Kwestionariusz opracowała Wioletta Junik na podstawie koncepcji rozwoju kompetencji zawodowych profilaktyka przygotowanej przez Krzysztofa Ostaszewskiego (2014). 
służyło do pomiaru znaczenia, jakie kadra akademicka, praktycy-profilaktycy oraz studenci (przyszli profilaktycy) przypisują określonej wiedzy i umiejętnościom niezbędnym do podejmowania skutecznych działań z zakresu profilaktyki zachowań ryzykownych dzieci i młodzieży. Dokonali oni również samooceny poziomu posiadanej wiedzy i umiejętności w tych samych obszarach. Zestawienie zakresu wiedzy oraz rodzajów umiejętności poddawanych samoocenie i ocenie ilustruje tabela 1 . Ustalenie rozbieżności między oceną znaczenia danego obszaru wiedzy a oceną własnego poziomu wiedzy w tym zakresie pozwalało wskazać obszary, w których można było się spodziewać największej motywacji wewnętrznej do rozwijania profilaktycznych kompetencji zawodowych przez ukraińskich partnerów oraz studentów.

Tabela. 1. Zakresy wiedzy i umiejętności poddanych ocenie i samoocenie beneficjentów programu w badaniu online.

\begin{tabular}{|l|l|}
\hline & $\begin{array}{l}\text { - Podstawy wiedzy o zachowaniach ryzykownych dzieci } \\
\text { i młodzieży }\end{array}$ \\
- Specyfika zachowań ryzykownych w okresie dzieciństwa \\
i adolescencii
\end{tabular}

Źródło: opracowanie własne.

Wyniki badania online ${ }^{13}$ pokazały, że wszystkie grupy badanych przypisywały duże znaczenie uwzględnionym w kwestionariuszu

13 Wyniki badań będą przedmiotem innej publikacji. 
obszarom wiedzy wskazanym jako niezbędne do podejmowania oddziaływań z zakresu profilaktyki zachowań ryzykownych dzieci i młodzieży. Średnie dla wszystkich badanych zmiennych w każdej badanej grupie znacznie przekraczały środek skali. Zbieżność wyników u wszystkich badanych miała miejsce również w obrębie samooceny poziomu tej wiedzy. Przy czym tu średni poziom samooceny we wszystkich obszarach wiedzy oscylował wokół środka skali. Taki sam trend wystąpił w przypadku umiejętności, gdzie wyższe były średnie wyniki dotyczące oceny znaczenia określonych umiejętności zawodowych profilaktyka niż średnie wyniki ilustrujące poziom ich samooceny w każdej z badanych grup. W związku z takim stanem rzeczy, obszary wiedzy i rodzaje umiejętności uwzględnione w diagnozie online zostały włączone do programu szkoleniowego projektu, którego realizację zaplanowano w formie seminariów naukowo-metodycznych i trzech sesji warsztatowych.

Pierwsze seminarium odbyło się na terenie UKW w 2017 roku, kolejne na terenie PUPIF w 2018 roku. Oprócz dzielenia się przez partnerów wiedzą naukową i doświadczeniem metodycznym, seminaria stanowily okazję do odbywania wizyt studyjnych w instytucjach i placówkach realizujących działania profilaktyczne w Polsce i w Ukrainie. Podstawowymi formami pracy seminaryjnej były wykłady interaktywne i warsztaty metodyczne. Łącznie przeprowadzono 49 godzin wykładów oraz 17 godzin warsztatów. Zrealizowało je trzech ekspertów zajmujących się profilaktyką opartą na naukowych podstawach z Polski i jeden z Ukrainy oraz trzyosobowy zespół z KPOiPS UKW. Natomiast poza seminariami przeprowadzono trzy dziesięciogodzinne warsztaty: rozwijania umiejętności interpersonalnych, wychowawczych i pracy z grupą dziecięcą oraz młodzieżową. Uczestnicy projektu wzięli udział w sześciogodzinnym bloku wykładowo-warsztatowym poświęconym projektowaniu procesu kształcenia na studiach wyższych w oparciu o zasady Systemu Bolońskiego. Każdy uczestnik projektu otrzymał również pakiet materiałów szkoleniowych w języku ukraińskim obejmujących pełne treści szkoleń, treści uzupełniające i użyte na szkoleniach karty pracy.

W tabeli 2. umieszczono się wykaz obszarów tematycznych oraz odpowiadających im treści włączonych do programu doskonalenia zawodowego dla kadry akademickiej PUPIF i praktyków-profilaktyków. 
Tabela 2. Treści programu doskonalenia zawodowego seminariów naukowo-metodycznych i sesji warsztatowych

\begin{tabular}{|c|c|}
\hline Obszar tematyczny & Wybrane zagadnienia \\
\hline Stan profilaktyki społecznej w Ukrainie & $\begin{array}{l}\text { - System profilaktyki społecznej na rzecz młodzieży } \\
\text { w Ukrainie: potrzeby i zasoby } \\
\text { - Aktualny stan działań nad wypracowywaniem skutecznych } \\
\text { metod profilaktyki uzależnień w Ukrainie } \\
\text { - Zasady projektowania kształcenia na studiach wyższych } \\
\text { według wymogów Systemu Bolońskiego w Ukrainie }\end{array}$ \\
\hline $\begin{array}{l}\text { Rozwój i funkcjonowanie systemu profilak- } \\
\text { tyki uzależnień w Polsce }\end{array}$ & $\begin{array}{l}\text { - Rozwój i historia systemu profilaktyki w Polsce } \\
\text { - Działalność agencii rzqdowych na rzecz rozwoju systemu } \\
\text { profilaktyki w Polsce na przykładzie PARPA } \\
\text { - Uregulowania prawne przeciwdziałania uzależnieniom } \\
\text { i profilaktyki w Polsce }\end{array}$ \\
\hline $\begin{array}{l}\text { Rozwój kompetencji zawodowych do } \\
\text { pracy profilaktycznej w Polsce i Ukrainie }\end{array}$ & $\begin{array}{l}\text { - Kompetencje zawodowe profilaktyka w Polsce i Ukrainie - } \\
\text { potrzeby a rzeczywistość } \\
\text { - Potrzeby partnerów ukraińskich projektu w zakresie } \\
\text { rozwoju kompetencji zawodowych do pracy } \\
\text { profilaktycznej - wyniki diagnozy online }\end{array}$ \\
\hline $\begin{array}{l}\text { Koncepcja i rozwiqzania stosowane } \\
\text { w kształceniu specjalistów z zakresu } \\
\text { profilaktyki na UKW w Bydgoszczy }\end{array}$ & $\begin{array}{l}\text { - Teoretyczne i metodyczne podstawy przygotowywania } \\
\text { studentów kierunku pedagogika o specjalności „Opieka } \\
\text { i wychowanie z profilaktykq społecznq” do podejmowania } \\
\text { zadań z zakresu profilaktyki ryzykownych zachowań dzieci } \\
\text { i młodzieży } \\
\text { - Charakterystyka kształcenia specjalistycznego do pracy } \\
\text { z zakresu profilaktyki społecznej na poziomie studiów } \\
\text { pierwszego stopnia } \\
\text { - Innowacyiność modułowego kształcenia pedagogów- } \\
\text {-profilaktyków na przykładzie kierunku pedagogika } \\
\text { opiekuńcza z profilaktykq uzależnień i socjoterapiq na } \\
\text { UKW w Bydgoszczy } \\
\text { - Istota i zasady projektowania kształcenia modułowego }\end{array}$ \\
\hline $\begin{array}{l}\text { Uwarunkowania i mechanizmy zachowań } \\
\text { ryzykownych dzieci i młodzieży }\end{array}$ & $\begin{array}{l}\text { - Teorie wyjaśniajace przyczyny ryzykownych zachowań } \\
\text { dzieci i młodzieży } \\
\text { - Uwarunkowania zachowań ryzykownych } \\
\text { - Czynniki i mechanizmy ryzyka } \\
\text { - Czynniki i mechanizmy chroniqqce } \\
\text { - Teorie wyjaśniajace pozyływnq adaptację i pozyływny } \\
\text { rozwój dzieci i młodzieży }\end{array}$ \\
\hline $\begin{array}{l}\text { Profilaktyka zachowań ryzykownych - } \\
\text { istota i podstawy }\end{array}$ & $\begin{array}{l}\text { - Teoretyczne i empiryczne podstawy profilaktyki zachowań } \\
\text { ryzykownych dzieci i młodzieży } \\
\text { - Profilaktyka ryzykownych zachowań dzieci i młodzieży } \\
\text { jako dziedzina interdyscyplinarna } \\
\text { - Profilaktyka ryzykownych zachowań dawniej i dziś } \\
\text { - Poziomy działań profilaktycznych }\end{array}$ \\
\hline
\end{tabular}




\begin{tabular}{|c|c|}
\hline Obszar tematyczny & Wybrane zagadnienia \\
\hline $\begin{array}{l}\text { Budowanie na naukowych podstawach } \\
\text { systemu wczesnei profilaktyki ryzykow- } \\
\text { nych zachowań dzieci i młodzieży }\end{array}$ & $\begin{array}{l}\text { - Teoretyczne podstawy koncepcji wczesnei profilaktyki } \\
\text { zachowań ryzykownych dzieci i młodzieży autorstwa } \\
\text { Marii Deptuły (2019) } \\
\text { - Rola pedagogów/nauczycieli zajmujących się wczesna } \\
\text { profilaktykq }\end{array}$ \\
\hline Jakość w profilaktyce & $\begin{array}{l}\text { - Zasady konstruowania programów profilaktycznych } \\
\text { - Formy i strategie profilaktyczne wiodqce i uzupełniajace } \\
\text { i ich skuteczność } \\
\text { - Ewaluacja w profilaktyce - paradygmaty, schematy, } \\
\text { metody i techniki badawcze } \\
\text { - Ewaluacja programów profilaktycznych - podstawowe } \\
\text { koncepcje i rozróżnienia }\end{array}$ \\
\hline $\begin{array}{l}\text { Dobre praktyki profilaktyczne w Polsce } \\
\text { i na świecie }\end{array}$ & $\begin{array}{l}\text { - Standardy profilaktyki według Biura ONZ ds. Narkotyków } \\
\text { i Przestępczości (UNODC) } \\
\text { - Baza programów rekomendowanych } \\
\text { - Cele systemu rekomendacji } \\
\text { - Poziomy rekomendacji } \\
\text { - Kryteria oceny jakości programu profilaktycznego } \\
\text { - Przegląd rekomendowanych programów profilaktycznych }\end{array}$ \\
\hline $\begin{array}{l}\text { Kompetencje profilaktyka do pracy } \\
\text { z jednostkq i grupq wychowawczq } \\
\text { profilaktycznq }\end{array}$ & $\begin{array}{l}\text { Podstawy rozwoju osobistego pedagoga/psychologa } \\
\text { profilaktyka } \\
\text { - Umiejętności wychowawcze pedagoga/psychologa } \\
\text { profilaktyka } \\
\text { - Umiejętności pedagoga/psychologa profilaktyka } \\
\text { niezbędne w pracy z grupq dzieci i młodzieży }\end{array}$ \\
\hline Profilaktyka w szkole & $\begin{array}{l}\text { Rola i zadania nauczycieli w profilaktyce zachowań } \\
\text { ryzykownych dzieci i młodzieży opartej na naukowych } \\
\text { podstawach }\end{array}$ \\
\hline $\begin{array}{l}\text { Profilaktyka zachowań ryzykownych } \\
\text { w wybranych grupach ryzyka }\end{array}$ & $\begin{array}{l}\text { - Teoretyczne i empiryczne podstawy profilaktyki uzależnień } \\
\text { behawioralnych i zachowań nałogowych } \\
\text { - Teoretyczne i metodyczne podstawy pracy socjoterapeu- } \\
\text { tycznej adresowanej do dzieci i młodzieży z grup ryzyka }\end{array}$ \\
\hline
\end{tabular}

Źródło: opracowanie własne.

W Ukrainie brakuje przetłumaczonych na język ukraiński publikacji naukowych, zarówno rodzimych, jak i zagranicznych popularyzujących szerzej podejście oparte na dowodach (ang. evidence-based prevention) i naukę o profilaktyce. Dlatego też w projekcie przewidziano przygotowanie do przetłumaczenia na język ukraiński dwóch wieloautorskich monografii naukowych ${ }^{14}$ poświęconych profilaktyce

14 Pierwsza monografia pt. Wczesna profilaktyka problemów w rozwoju psychospotecznym i ryzykownych zachowań dzieci i mtodzieży, autorstwa M. Deptuły, A. Potorskiej, S. Borsicha, została już wydana przez Wydawnictwo 
zachowań ryzykownych dzieci i młodzieży. Ich adresatami byliby bezpośredni i pośredni uczestnicy projektu oraz wszystkie osoby zainteresowane wiedzą naukową z zakresu profilaktyki zachowań ryzykownych dzieci i młodzieży. W celu umożliwienia jak najszerszego dostępu do monografii zaplanowano ich wydanie w formie papierowej i elektronicznej (do zamieszczenia w repozytoriach na stronach internetowych partnerskich uniwersytetów i PARPA). Pierwsza monografia w języku polskim i ukraińskim jest już promowana i dystrybuowana na terenie Polski i Ukrainy za pośrednictwem UKW, PUPIF oraz PARPA.

\section{Etap II}

Realizację tego etapu zaplanowano na 2019 rok. Jego celem jest wypracowanie przez partnerów ukraińskich wspólnej koncepcji i modułu kształcenia dla dwóch kierunków studiów pierwszego stopnia: psychologia praktyczna i praca socjalna. Pierwszym zadaniem było zorganizowanie przez koordynatorkę projektu spotkania roboczego całego zespołu projektowego celem podziału zadań i podjęcia pierwszych prac nad koncepcją kształcenia. Następnie profilaktycy-praktycy przystąili do opracowania koncepcji praktycznego kształcenia studentów analizując potrzeby z zakresu profilaktyki oraz odwołując się do własnej praktyki zawodowej. W tym samym czasie kadra akademicka przygotowywała teoretyczną część modułu kształcenia. Następnie grupy spotkały się razem, by przedstawić wypracowane koncepcje kształcenia teoretycznego i praktycznego oraz podjąć próbę połączenia ich w całość. W międzyczasie odbywały się konsultacje online pomiędzy stroną ukraińską i zespołem z KPOiPS. Niestety brak jasnych uregulowań prawnych dotyczących realizacji zadań profilaktycznych w oświacie (potencjalnym miejscu praktyk dla studentów) stanowił przeszkodę w projektowaniu koncepcji kształcenia praktycznego i utrudniał sformułowanie efektów kształcenia praktycznego oraz dobór sposobów ich realizacji. Poza tym przygotowywanie

Naukowe PWN w 2018 roku w j. polskim w formie papierowej i elektronicznej. Wersję ukraińską Рання профілактика проблем психосоиіального розвитку і ризикованої поведінки дітей та молодi wydało Wydawnictwo UKW w Bydgoszczy. Praca trafiła już do partnerów. Druga monografia jest $\mathrm{w}$ przygotowaniu. 
koncepcji kształcenia przez kadrę akademicką z udziałem interesariuszy zewnętrznych było nowym wyzwaniem, ponieważ ten sposób projektowania procesu kształcenia dopiero rozwija się w Ukrainie. Dlatego też nie udało się zespołom na tym etapie opracować spójnej koncepcji kształcenia teoretycznego i praktycznego.

Dalsze prace nad modułem zaplanowano przy bezpośrednim udziale zespołu z KPOiPS podczas III Seminarium naukowo-metodycznego na PUPIF i ośmiogodzinnych, trzydniowych superwizji dla zespołu ukraińskiego przy pracach nad ostateczną wersją modułu kształcenia. $\mathrm{Na}$ zakończenie seminarium zaprezentowano treści dotyczące innowacyjności w kształceniu profilaktyków oraz dobrych praktyk w zakresie przygotowywania studentów do realizacji działań profilaktycznych w szkole. $Z$ kolei superwizje polegały na analizowaniu wspólnie $\mathrm{z}$ autorami modułu procedury jego konstruowania ze zwróceniem uwagi na zachowanie standardów Systemu Bolońskiego oraz na doradztwie w zakresie poszukiwania naukowych uzasadnień formułowania efektów kształcenia i treści przedmiotowych im odpowiadających w dorobku naukowej profilaktyki. Strona polska pomagała w poszukiwaniu literatury naukowej niezbędnej do przygotowywania i realizacji procesu kształcenia. W rezultacie kadra akademicka PUPIF opracowała strukturę modułu kształcenia dla dwóch kierunków prezentowaną w tabeli 3, która obejmuje 120 godzin kształcenia teoretycznego i 90 godzin kształcenia praktycznego.

Tabela 3. Plan modułu kształcenia

\begin{tabular}{|c|c|c|c|c|c|c|c|c|}
\hline \multicolumn{3}{|c|}{ Kierunek studiów/specjalność } & \multirow[b]{2}{*}{ Semestr } & \multirow[b]{2}{*}{$\begin{array}{l}\text { Godzi- } \\
\text { ny/pkt. } \\
\text { ECTS }\end{array}$} & \multirow[b]{2}{*}{$\begin{array}{l}\text { Liczba } \\
\text { godzin } \\
\text { ogółem }\end{array}$} & \multirow[b]{2}{*}{ Wykłady } & \multirow[b]{2}{*}{$\begin{array}{c}\text { Ćwicze- } \\
\text { nia }\end{array}$} & \multirow[b]{2}{*}{$\begin{array}{l}\text { Praca } \\
\text { samo- } \\
\text { dzielno }\end{array}$} \\
\hline $\begin{array}{l}\text { Praca } \\
\text { socjalna }\end{array}$ & $\begin{array}{c}\text { Psycho- } \\
\text { logia / } \\
\text { prakłyczna }\end{array}$ & Socjologia & & & & & & \\
\hline \multicolumn{3}{|c|}{ Profilaktyka społeczna } & 4 & $90 / 3$ & 30 & 15 & 15 & 60 \\
\hline \multicolumn{3}{|c|}{$\begin{array}{l}\text { Teoretyczne podstawy profilaktyki } \\
\text { zachowań ryzykownych }\end{array}$} & 5 & $90 / 3$ & 30 & 15 & 15 & 60 \\
\hline \multicolumn{3}{|c|}{$\begin{array}{l}\text { Diagnozowanie i projektowanie } \\
\text { w profilaktyce zachowań ryzykow- } \\
\text { nych }\end{array}$} & 6 & $90 / 3$ & 30 & 15 & 15 & 60 \\
\hline $\begin{array}{l}\text { Profilak- } \\
\text { tyka } \\
\text { w insty- } \\
\text { tucjach } \\
\text { oświaty }\end{array}$ & $\begin{array}{l}\text { Psychopro- } \\
\text { filaktyka } \\
\text { uzależnień }\end{array}$ & $\begin{array}{l}\text { Profilak- } \\
\text { tyka } \\
\text { w grupach } \\
\text { społecz- } \\
\text { nych }\end{array}$ & 6 & $90 / 3$ & 30 & 15 & 15 & 60 \\
\hline
\end{tabular}




\begin{tabular}{|c|c|c|c|c|c|c|c|c|}
\hline \multicolumn{3}{|c|}{ Kierunek studiów/specjalność } & \multirow[b]{2}{*}{ Semestr } & \multirow[b]{2}{*}{$\begin{array}{l}\text { Godzi- } \\
\text { ny/pkt. } \\
\text { ECTS }\end{array}$} & \multirow[b]{2}{*}{$\begin{array}{l}\text { Liczba } \\
\text { godzin } \\
\text { ogółem }\end{array}$} & \multirow[b]{2}{*}{ Wykłady } & \multirow[b]{2}{*}{$\begin{array}{c}\text { Ćwicze- } \\
\text { nia }\end{array}$} & \multirow[b]{2}{*}{$\begin{array}{l}\text { Praca } \\
\text { samo- } \\
\text { dzielna }\end{array}$} \\
\hline $\begin{array}{l}\text { Praca } \\
\text { socjalna }\end{array}$ & $\begin{array}{c}\text { Psycho- } \\
\text { logia / } \\
\text { praktyczna }\end{array}$ & Socjologia & & & & & & \\
\hline $\begin{array}{l}\text { Praktyka } \\
\text { socjalno- } \\
\text {-pedago- } \\
\text { giczna }\end{array}$ & $\begin{array}{l}\text { Praktyka } \\
\text { profilak- } \\
\text { tyczna } \\
\text { w pracy } \\
\text { psycholo- } \\
\text { ga-prak- } \\
\text { tyka }\end{array}$ & $\begin{array}{l}\text { Praktyka } \\
\text { socjolo- } \\
\text { giczna }\end{array}$ & $6 / 8 / 6$ & $90 / 3$ & & & & \\
\hline
\end{tabular}

Źródło: opracowanie własne.

Ostatnie zadanie, nad którym pracują obecnie partnerzy ukraińscy, polega na opracowywaniu szczegółowej dokumentacji wymaganej do monitorowania jakości kształcenia na każdym kierunku studiów w postaci opisu efektów kształcenia, programów nauczania do wszystkich uwzględnionych w module przedmiotów nauczania, opisu sylwetki absolwenta, opisu sposobów weryfikacji efektów kształcenia, próbki narzędzi do weryfikacji tych efektów. Ostatnim zadaniem kierownika projektu jest opracowanie raportu końcowego z realizacji całego projektu w języku polskim i ukraińskim do zamieszczenia na stronach internetowych instytucji zaangażowanych w realizację projektu. Raport ma służyć popularyzacji dobrej praktyki inspirującej inne uczelnie do modyfikowania procesu kształcenia i włączania w jego przebieg struktur umożliwiających rozwijanie kompetencji studentów do pracy profilaktycznej opartej na naukowych podstawach, na którą istnieje coraz większe zapotrzebowanie w społeczeństwie ukraińskim.

\section{Wnioski}

Realizacja tego rodzaju projektów o charakterze międzynarodowym obarczona jest ryzykiem związanym $\mathrm{z}$ ingerowaniem w odmienny kulturowo system funkcjonowania jednostek i instytucji. Antidotum na zagrożenia $\mathrm{z}$ tym związane jest przyjęcie określonych założeń i zasad dotyczących partnerstwa. Cennym rozwiązaniem jest intencjonalne wprowadzenie „kultury współpracy” do wzajemnych relacji, która sprzyja osiąganiu wspólnych celów za sprawą dbałości 
o poszanowanie podmiotowości partnera, między innymi poprzez wzmacnianie poczucia sprawstwa na każdym etapie realizacji projektu. Tak też było w przypadku niniejszego projektu. Wdrożenie idei „kultury współpracy” przyczyniło się do zbudowania stosunków partnerskich opartych na zaufaniu wyrażanym w bezpośrednich kontaktach, jak również zaowocowało wartością dodaną w postaci zawartej umowy o wspólpracy pomiędzy uniwersytetami, planów dalszej współpracy, nawiązania kontaktów z innymi partnerami za pośrednictwem instytucji partnerskiej. Jednak przede wszystkim owocuje obopólną satysfakcją z realizacji dobrej praktyki projektowej, wyrażaną w postaci dzielenia się dotychczasowym doświadczeniem projektowym podczas wspólnych wystąpień na konferencjach międzynarodowych w Ukrainie i Polsce oraz poza ich granicami.

Projekty tego typu są ważnym elementem budowania międzynarodowej koalicji na rzecz wspólnego rozwiązywania problemów społecznych, opartej na dzieleniu się własnymi zasobami w postaci wiedzy i dobrych praktyk. Łączenie wysiłków jest szczególnie ważne w kwestii inwestowania w zdrowie młodego pokolenia, które stanowi przyszłość każdego społeczeństwa.

\section{Bibliografia}

Franke E. (2016). Rodzaje wiedzy i źródta jej pozyskiwania we wspótczesnym przedsiębiorstwie w aspekcie organizacji uczacej się, ,Zeszyty Naukowe Politechniki Śląskiej. Organizacja i Zarządzanie”, z. 87, s. 105-118.

Maslowski R. (2006). A Review of Inventories for Diagnosing School Culture, „Journal of Educational Administration”, t. 44, nr 1, 6-35. DOI: $10.1108 / 09578230610642638$.

OECD (2000). Knowledge management in the learning society, Paris: OECD.

Okulicz-Kozaryn K., Shchudlo S., Klymanska L., Herasym H., Herus O., Savka V., Mirchuk I. (2017). Zachowania ryzykowne i zaburzenia zdrowia psychicznego mtodzieży we Lwowie, Drohobyczu $i$ w powiecie drohobyckim, [w:] K. Ostaszewski (red.), Monitorowanie zachowań ryzykownych, zachowań natogowych i problemów zdrowia psychicznego 15-letniej mtodzieży. Badania mokotowskie 2004-2016. Badania ukrainskie, obwód lwowski 2016, Warszawa: Instytut Psychiatrii i Neurologii w Warszawie, s. $129-146$.

Ostaszewski K. (2014). Kompetencje zawodowe profilaktyka, „Serwis Informacyjny Narkomania”, nr 4(68), s. 8-13. 
Ostaszewski K. (red.). (2017). Używanie substancji psychoaktywnych jako przejaw zachowań ryzykownych mtodzieży szkolnej, „Dziecko Krzywdzone”, t. 16, nr 1, s. 133-143, <http://dzieckokrzywdzone.fdds.pl/index. $\mathrm{php} / \mathrm{DK} /$ article/view/579> [dostęp: 20.06.2019].

Szczudło S. (2014). Mtodzież studencka Ukrainy w spoteczeństwie ryzyka, [w:] P. Długosz, M. Niezgoda, S. Solecki (red.), Mtodzież w spoteczeństwie ryzyka, Kraków: Wydawnictwo UJ, s. 173-187.

Tłuściak-Deliowska A., Dernowska, U. (2016). Kultura wspótpracy w szkole w percepcji nauczycieli szkót gimnazjalnych, „Studia Edukacyjne”, nr 40, 127-148. DOI: 10.14746/se.2016.40.8.

\section{Netografia}

Balakireva O.M., Bondar T.V., Prijmak Y.Y., Pavlova D.M., Vasilenko O.V., Sakovich O.T., Sal'nikov S.Z., Sidyak S.V., Yudin Y.B., Nahabich N.S. (2015). Kurinnya, vzhyvannya alkogolyu ta narkotychnyh rechovyn sered pidlitkiv, yaki navchayut'sya: Poshyrennya i tendencji v Ukraini: $\mathrm{Za}$ rezul'tatami doslidzhennya 2015 roku v ramkah mizhnarodnogo projektu «Evropejs'ke opytuvannya uchniv shchodo vzhyvannya alkogolyu ta inshyh narkotichnyh rechooyn - ESPAD", Kyiv: Ukrains'kyj instytut social'nyh doslidzhen' im. Oleksandra Yaremenka, <https://www.unicef.org/ukraine/reports/smoking-use-alcohol-and-drugs-among-adolescents-education-distribution-and-trends-ukraine> [dostęp: 19.06.2019].

Кабінет Міністрів України. (2013). Розпорядження, Про схвалення Стратегії державної політики щодо наркотиків на період до 2020 року. Від 28 серпня 2013 p. № 735-p, <https://www.kmu.gov.ua/ npas/246715472> [dostęp: 20.06.2019].

The World Factbook 2016-17. (2016). <https://www.cia.gov/library/publications/the-world-factbook/index.html> [dostęp: 19.06.2019].

World Health Organization: Ukraine. Conflict emergency. <https://www.who. int/hac/crises/ukr/sitreps/ukraine_sitrep_1august2016.pdf?ua=1> [dostęp: 19.06.2019].

World Health Organization: Ukraine health situation reports. <https://www. who.int/emergencies/crises/ukr/sitreps/en/> [dostęp: 16.06.2019].

World Health Organization: Ukraine. Statistics. <http://www.who.int/countries/ukr/en/> [dostęp: 23.05.2017].

\section{ADRES DO KORESPONDENCJ}

Dr Wioletta Junik

Uniwersytet Kazimierza Wielkiego w Bydgoszczy

Wydział Pedagogiki i Psychologii

e-mail: wioletta.junik@ukw.edu.pl 